\title{
Important factors associated with sick leave after allogeneic haematopoietic stem cell transplantation-a 1-year prospective study
}

\author{
Linda Eriksson $^{1,2}$ (D) Agneta Wennman-Larsen ${ }^{3,4} \cdot$ Karin Bergkvist $^{1,4} \cdot$ Per Ljungman $^{5,6}$. Jeanette Winterling $^{1,2}$
}

Received: 20 October 2020 / Accepted: 24 December 2020 / Published online: 8 January 2021

(C) The Author(s) 2021

\begin{abstract}
Purpose This study examines sick leave (SL) and factors associated with full-time SL 1 year after allogeneic haematopoietic stem cell transplantation (allo-HSCT) in patients of working age from 2009 to $2016(n=122)$.

Methods Questionnaire data were collected on admission to the allo-HSCT unit, at 7 months and 1 year after allo-HSCT. Associations between factors and SL were analysed using logistic regression analyses.

Results One year after allo-HSCT, $76 \%$ of participants were on SL, with $36 \%$ on full-time SL. In univariable analyses, chronic graft-versus-host-disease (cGvHD) (OR 3.07; 95\% CI 1.34-7.07; $p=0.01$ ), having symptoms of depression at 7 months (OR $4.81 ; 95 \%$ CI $1.69-13.69 ; p=0.00)$ and low levels of vocational satisfaction at 7 months after treatment (OR 3.27; 95\% CI 1.27$8.41 ; p=0.01)$ were associated with full-time SL 1 year after allo-HSCT. cGvHD (OR 3.43; 95\% CI 1.35-8.73; $p=0.01)$ and having symptoms of depression at 7 months after allo-HSCT (OR 3.37; 95\% CI 1.2-11.58; $p=0.02)$ remained significant in multivariable analysis.

Conclusion The majority of allo-HSCT survivors were on SL 1 year after treatment, and cGvHD, low vocational satisfaction and depressive symptoms were associated with full-time SL 1 year after allo-HSCT.

Implications for Cancer Survivors Healthcare professionals need to be observant of and manage the consequences of cGvHD and patients' symptoms of depression in order to support them appropriately in their return-to-work process.
\end{abstract}

Keywords Allogeneic haematopoietic stem cell transplantation $\cdot$ Sick leave $\cdot$ Sickness absence $\cdot$ Return to work

Linda Eriksson

linda.eriksson@ki.se

1 Department of Neurobiology, Care Sciences and Society, Division of Nursing, Karolinska Institutet, Alfred Nobels allé 23, C4, 141 52 Stockholm, Sweden

2 Department of Haematology, Karolinska University Hospital, Stockholm, Sweden

3 Department of Clinical Neuroscience, Division of Insurance Medicine, Karolinska Institutet, Stockholm, Sweden

4 Sophiahemmet University, Stockholm, Sweden

5 Department of Medicine Huddinge, Division of Haematology, Karolinska Institutet, Stockholm, Sweden

6 Department of Cellular Therapy and Allogeneic Stem Cell Transplantation, Karolinska University Hospital Huddinge, Stockholm, Sweden

\section{Introduction}

An allogeneic haematopoietic stem cell transplantation (alloHSCT) is a procedure where healthy haematopoietic stem cells from a donor are infused to a recipient to replace stem cells that are defect from the underlying disease or treatment in the hope that the recipient will recover the ability to produce their own healthy haematopoietic stem cells. Prior to alloHSCT, patients receive chemotherapy and/or radiation therapy in order to suppress their underlying malignancy and facilitate the engraftment of the new stem cells [1]. It is a demanding and intensive treatment that often results in many longlasting disease and treatment-related difficulties that negatively affect patients health [2,3], making those who are of working age unable to work or study [4]. After an allo-HSCT, an important goal is to return to normal life, which includes return to work (RTW) as it can represent a return to normality [5] and often increases quality of life [6].

Research has shown that factors associated with a lower likelihood of RTW for allo-HSCT survivors include female 
gender, older age, poorer health and worse physical functioning $[4,7]$ along with fatigue, pain and lower quality of life $[6$, 8]. The most common late complication of allo-HSCT is chronic graft-versus-host-disease (cGvHD), which affects $20-50 \%$ of survivors [9]. GvHD is an immune reaction mediated by $\mathrm{T}$ cells between the donated stem cells and the recipient [1]. The first phase of this immune response, acute GvHD (aGvHD), causes direct tissue damage in varying degrees and generally manifests in a set of organs (i.e. skin, liver and gastrointestinal tract) [1]. The second phase, cGvHD, tends to be more delayed in its presentation and involves a broader set of organs that can bear strong resemblances to autoimmune disorders [1]. Whether cGvHD has an effect on RTW is not clear as some studies state there is no association $[7,10]$ whereas other studies suggest that there is a relationship between the two $[9,11]$. These mixed results can depend on differences in study design, sample size and treatment regimes. Due to the psychological challenges associated with allo-HSCT, patients are at risk of anxiety and depression [12-15], and previous research has found that patients with a haematological malignancy who showed symptoms of anxiety were less likely to RTW [8]. Satisfaction with one's vocational and financial situation may also influence RTW. Earlier studies on non-haematological patients indicate that low satisfaction with one's vocational [16-18] and financial situation [19] is associated with reduced RTW.

Long periods of sick leave (SL) can have a negative impact on areas such as health, work, social relationships and financial situation causing changes in self-image, feelings of exclusion and social stigma [20-25]. The prerequisites of being on SL differ between countries. In Sweden, everyone with an income from work, unemployment benefits, studies or parental leave benefit is covered by the national social insurance and qualifies for sickness benefits if unable to work due to disease or injury that reduces their work ability by at least $25 \%$. The levels of compensation can be $25,50,75$ or $100 \%$ of regular work hours depending on the reduction in work ability, covering approximately $80 \%$ of lost income up to a certain level. Identifying alloHSCT patients at risk of long-term SL may help improve rehabilitation and increase quality of life. Hence, the aim of this study was to examine SL 1 year after allo-HSCT and its association with demographic, medical, and psychological factors, together with vocational and financial satisfaction.

\section{Materials and methods}

This is a longitudinal, prospective single-centre study using data collected at the time of allo-HSCT, 7 months and 1 year after allo-HSCT.

\section{Sample}

All consecutive adult patients admitted for allo-HSCT between March 2009 and January 2016 were screened, and those fulfilling the inclusion criteria were approached. Inclusion criteria were haematological disease, age 18-65 years, able to understand Swedish and living in Sweden (Fig. 1). In total, 321 patients met the inclusion criteria of whom 237 (74\%) agreed to participate, while the remainder $(n=84)$ either declined participation or were not invited to participate. The reasons for the latter were not recorded but are likely to have been due to the staff being too busy or the patient too sick. At baseline, 237 questionnaires were handed out and 194 responded ( $82 \%$ response rate). Only those who responded to the questionnaire at all three time points $(n=136)$ and did not report early retirement or disability pension $(n=14)$ at any time point were included $(n=122)$.

\section{Procedure}

When admitted to the allo-HSCT unit, eligible participants were given both verbal and written information, including a consent form. Baseline questionnaire data were collected on admission to the allo-HSCT unit, and follow-ups were at 7 months post allo-HSCT and close to the 1-year medical follow-up visit. Follow-up questionnaires were sent by post. If it was not returned, the participants were reminded twice by phone. Questionnaires were sent out at all time points to all participants, regardless of whether they had answered the previous questionnaires unless the participant had declined or died.

\section{Data collection}

Medical data was retrieved from the participants' medical records. Data regarding demographics, psychological factors, life satisfaction and sick leave were gathered from a questionnaire originally developed for breast cancer patients [26], which has previously been used on allo-HSCT patients $[4$, 27].

Sick leave was reported by the question "Are you on sick leave now?" with the response alternatives; "no" and "yes". Participants also responded to questions about "Full-time sick leave" or "Part time sick leave" with space to write the percentage of SL. Equivalent data were gathered from the medical records of participants who did not reply to this question. In this study, participants were considered as being on SL if they had been sick listed for at least 90 continuous days and full-time SL if they reported being on SL > 75\% of a full-time position.

Anxiety and depression were measured using the validated self-assessment Hospital Anxiety and Depression Scale (HADS) [28]. The scale consists of two subscales (anxiety 
Fig. 1 Enrolment of study participants

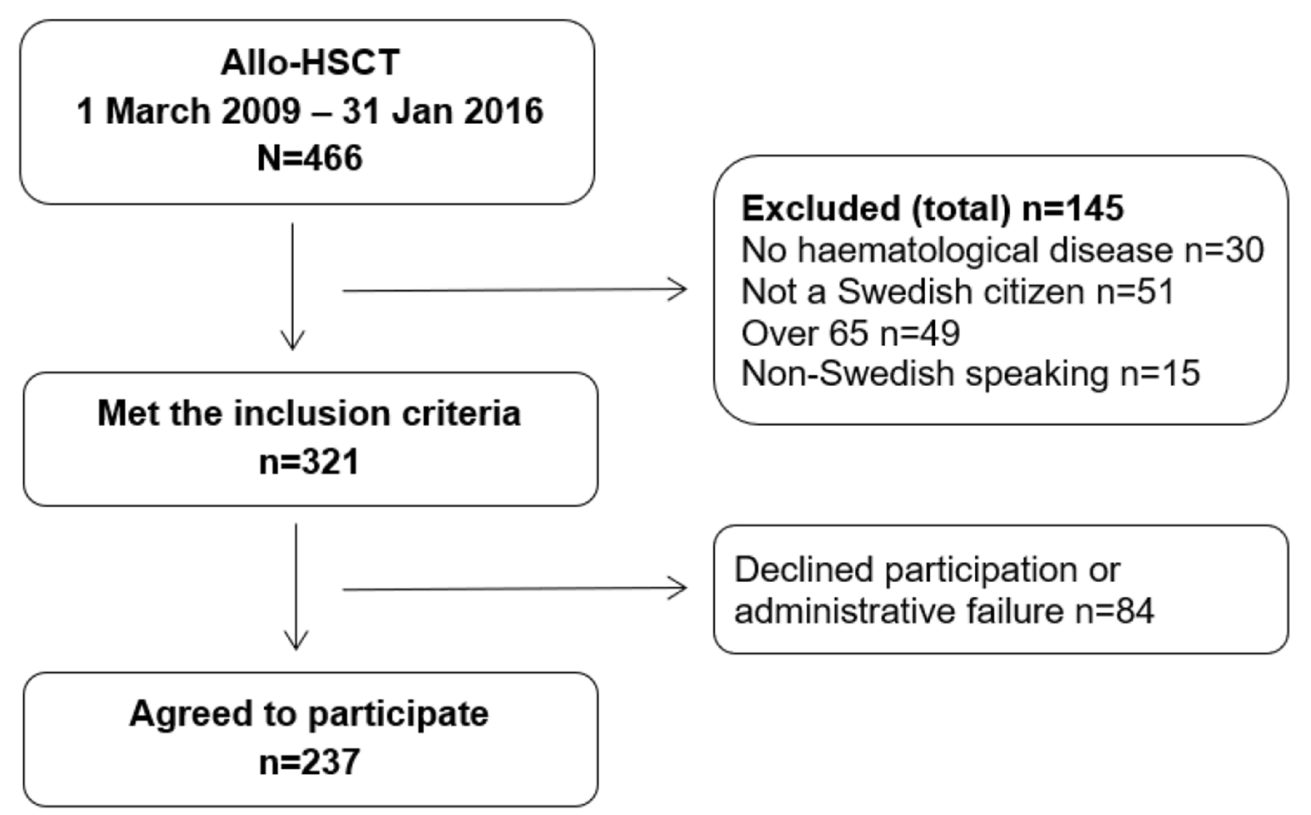

and depression) with seven items each. Each item is scored from 0 to 3 . Total scores for each subscale are calculated (ranging from 0 to 21). A higher score indicates higher levels of anxiety and/or depression. The cutoff value for symptoms of either anxiety and/or depression was $\geq 8$ [29].

Life satisfaction was measured using the validated Life Satisfaction Checklist-11 (LiSat-11) [30]. Two items were used; satisfaction with vocational situation and satisfaction with financial situation. The participants rated each item on a 6-point scale from "very dissatisfied" to "very satisfied". The answers were dichotomised into "low satisfaction" ("very dissatisfied to "rather satisfied") ) and "high satisfaction" ("satisfied" to "very satisfied").

\section{Statistical analyses}

Potential statistical differences between baseline respondents and non-respondents were analysed using either independent $t$ tests or two-sided $\chi 2$-tests depending on the data level. Missing data in instruments based on sum scores, i.e. HADS, were replaced using person-mean imputation [31] if missing data did not exceed $20 \%$ for each scale [32]. Odds ratios (OR) with $95 \%$ confidence intervals (CI) were calculated using univariable logistic regression analyses between each factor and full-time SL 1 year after allo-HSCT. The significance level was set to $p<0.05$. Factors analysed were demographic (gender, age, living situation, education), medical (diagnosis, conditioning, total body irradiation, relapse, presence of cGvHD), psychological (symptoms of anxiety and depression) and satisfaction with vocational and financial situation. A multivariable logistic regression was then performed where all factors with a $p$ value $\leq 0.05$ in the univariable analyses were included. The statistical calculations were conducted using SPSS 24.0 (IBM, Chicago, IL, USA).

\section{Results}

There were no statistically significant differences between baseline respondents $(n=194)$ and non-respondents $(n=43)$ regarding age and diagnosis, but a statistically significant difference was found regarding gender with females participating to a higher degree $\left(X^{2}(1)=4.6, p=0.03\right)$.

Medical and sociodemographic data are presented in Table 1 . The proportion having symptoms of anxiety did not differ much between baseline and 7 months post-allo-HSCT, with $25 \%$ of the participants scoring above the cutoff value at baseline and $24 \%$ at 7 months. The proportion having symptoms of depression decreased slightly from baseline $(21 \%)$ to 7 months post-treatment (17\%). At baseline, approximately half of the participants reported low levels of satisfaction (i.e. very dissatisfied to rather satisfied) with their vocational (55\%) and financial situation (49\%). At 7 months after alloHSCT, the number of participants reporting low levels of satisfaction increased for both vocational $(71 \%)$ and financial situation $(63 \%)$.

\section{Description of SL from diagnosis to 1 year after allo- HSCT}

Before diagnosis of their haematological disease, $98 \%$ of participants were working or studying full-time and only $2 \%$ reported being on SL. At baseline, when they were admitted for the allo-HSCT, 94\% were on SL. Those not on SL at baseline stated that they were self-employed. Seven months 
Table 1 Baseline demographic and medical data of the participants in the study $(n=122)$

\begin{tabular}{|c|c|c|}
\hline \multicolumn{2}{|l|}{ Demographic data } & \multirow{2}{*}{$\frac{n(\%)}{49(40)}$} \\
\hline Gender & Women & \\
\hline & Men & $73(60)$ \\
\hline \multirow[t]{2}{*}{ Age } & Younger $(<52 \text { years })^{1}$ & $58(48)$ \\
\hline & Older $(\geq 52$ years $)$ & $64(52)$ \\
\hline \multirow[t]{2}{*}{ Marital status } & Married & $77(63)$ \\
\hline & Not married & $40(33)$ \\
\hline \multirow[t]{2}{*}{ Living situation } & Living alone & $17(13)$ \\
\hline & Living with someone & $102(87)$ \\
\hline \multirow[t]{2}{*}{ Children } & Yes & $93(76)$ \\
\hline & No & $26(21)$ \\
\hline \multirow[t]{2}{*}{ Education } & Lower (elementary/secondary school) & $45(38)$ \\
\hline & Higher (college/university) & $74(62)$ \\
\hline \multirow[t]{2}{*}{ Country of birth } & Sweden & $107(88)$ \\
\hline & Abroad & $11(9)$ \\
\hline Medical data & & $n(\%)$ \\
\hline \multirow[t]{7}{*}{ Diagnosis } & Acute leukaemia & $51(42)$ \\
\hline & Chronic leukaemia & $24(20)$ \\
\hline & Lymphoma & $10(8)$ \\
\hline & Plasma cell disorders & $10(8)$ \\
\hline & Myelodysplastic syndrome & $16(13)$ \\
\hline & Myeloproliferative neoplasia & $7(6)$ \\
\hline & Other $^{2}$ & $4(3)$ \\
\hline \multirow[t]{2}{*}{ Conditioning } & Myeloablative & $84(69)$ \\
\hline & Reduced intensity & $38(31)$ \\
\hline \multirow[t]{2}{*}{ Total body irradiation } & Yes & $86(70)$ \\
\hline & No & $36(30)$ \\
\hline \multirow[t]{7}{*}{ Clinical status at allo-HSCT } & Complete remission & $74(61)$ \\
\hline & Partial remission & $24(20)$ \\
\hline & Chronic phase & $9(7)$ \\
\hline & No response & $2(2)$ \\
\hline & Stable disease & $6(5)$ \\
\hline & Untreated & $3(2)$ \\
\hline & Not applicable & $4(3)$ \\
\hline \multirow[t]{2}{*}{ Stem cell source } & Bone marrow & $14(12)$ \\
\hline & Peripheral blood & $108(88)$ \\
\hline \multirow[t]{3}{*}{ Type of donor } & Identical sibling, syngeneic & $41(34)$ \\
\hline & Unrelated $^{1}$ & $78(64)$ \\
\hline & Mismatched relative & $3(2)$ \\
\hline \multirow[t]{2}{*}{ Retransplantation (during 1st year after allo-HSCT) } & No & $116(95)$ \\
\hline & Yes & $6(5)$ \\
\hline \multirow[t]{4}{*}{ cGvHD (at 1 year) } & No & $90(74)$ \\
\hline & Mild & $20(16)$ \\
\hline & Moderate & $12(10)$ \\
\hline & Severe & - \\
\hline \multirow[t]{2}{*}{ Relapse (during 1st year after allo-HSCT) } & No & $108(88)$ \\
\hline & Yes & $14(12)$ \\
\hline
\end{tabular}


after allo-HSCT, $90 \%$ of the participants were on either fullor part-time SL, which dropped to $76 \% 1$ year after alloHSCT. One year after treatment, $39 \%$ of all participants were on full-time SL. The proportions of levels of compensation and those on full-time SL (> 75-100\%), part-time SL (1-75\%) or no SL from pre-diagnosis to 1 year after allo-HSCT can be seen in Fig. 2.

\section{Factors associated with full-time SL 1 year after allo- HSCT}

In univariable analyses, the factors associated with full-time SL 1 year after allo-HSCT were cGvHD (OR 3.07; 95\% CI $1.34-7.07 ; p=0.01)$, having symptoms of depression at 7 months (OR 4.81; 95\% CI 1.69-13.69; $p=0.00)$ and low levels of satisfaction regarding vocational situation at 7 months (OR 3.27; 95\% CI 1.27-8.41; $p=0.01$ ) (Table 2). Gender, age, education, living situation, diagnosis, conditioning treatment, total body irradiation, relapse, having symptoms of anxiety and satisfaction with financial situation were not associated with full-time SL 1 year after allo-HSCT. The only factors independently associated with full-time SL 1 year after allo-HSCT in the multivariable analysis were cGvHD (OR 3.43; 95\% CI 1.35-8.73; $p=0.01$ ) and having symptoms of depression at 7 months (OR 3.37; 95\% CI 1.2-11.58; $p=$ 0.02) (Table 2).

\section{Discussion}

This is the first longitudinal study focusing on SL during the first year after allo-HSCT. The results show that $39 \%$ of the participants were on full-time SL 1 year after allo-HSCT and that factors of importance for SL were symptoms of depression at the 7-month follow-up together with cGvHD 1 year after treatment.

Examination of SL during the first year after allo-HSCT revealed that almost all participants were on full-time SL at the time of allo-HSCT and although the percentage decreased over time, 39\% were still on full-time SL 1 year after treatment. No studies investigating SL after allo-HSCT were found with which to compare the present results. However, a longitudinal study found that of patients who had undergone an autologous HSCT due to relapse after treatment for lymphoma, 30\% remained on SL after the first year (part- or full-time SL unknown) $(n=164)$ [33]. Several studies have examined RTW among HSCT patients and estimates range from $20 \%$ to approximately $45 \%$ of patients returning to full-time work 1 year after transplantation in research including both autologous and allogeneic participants [10, 11, 7, 33]. Moreover, fewer allogeneic patients RTW within the first year after transplantation compared to autologous patients [11].

Comparing allo-HSCT patients with other cancer diagnoses can be problematic, as treatment regimens vary considerably, but studies have revealed that chemotherapy can significantly prolong SL and delay RTW [34-37]. However, in the present study, $76 \%$ were on either part- or full-time SL, which is a large proportion compared to, e.g. breast cancer patients in Sweden, where close to $30 \%$ were on SL (with less than $10 \%$ on full-time SL) 1 year after treatment [38]. Furthermore, being on SL for longer periods of time can in itself be associated with difficulties related to RTW among patients with different types of cancer diagnoses [39].

An explanation for the high proportions of being on SL in this study could be that clinicians recommend all allo-HSCT patients to take full-time SL for at least 6 months unless they

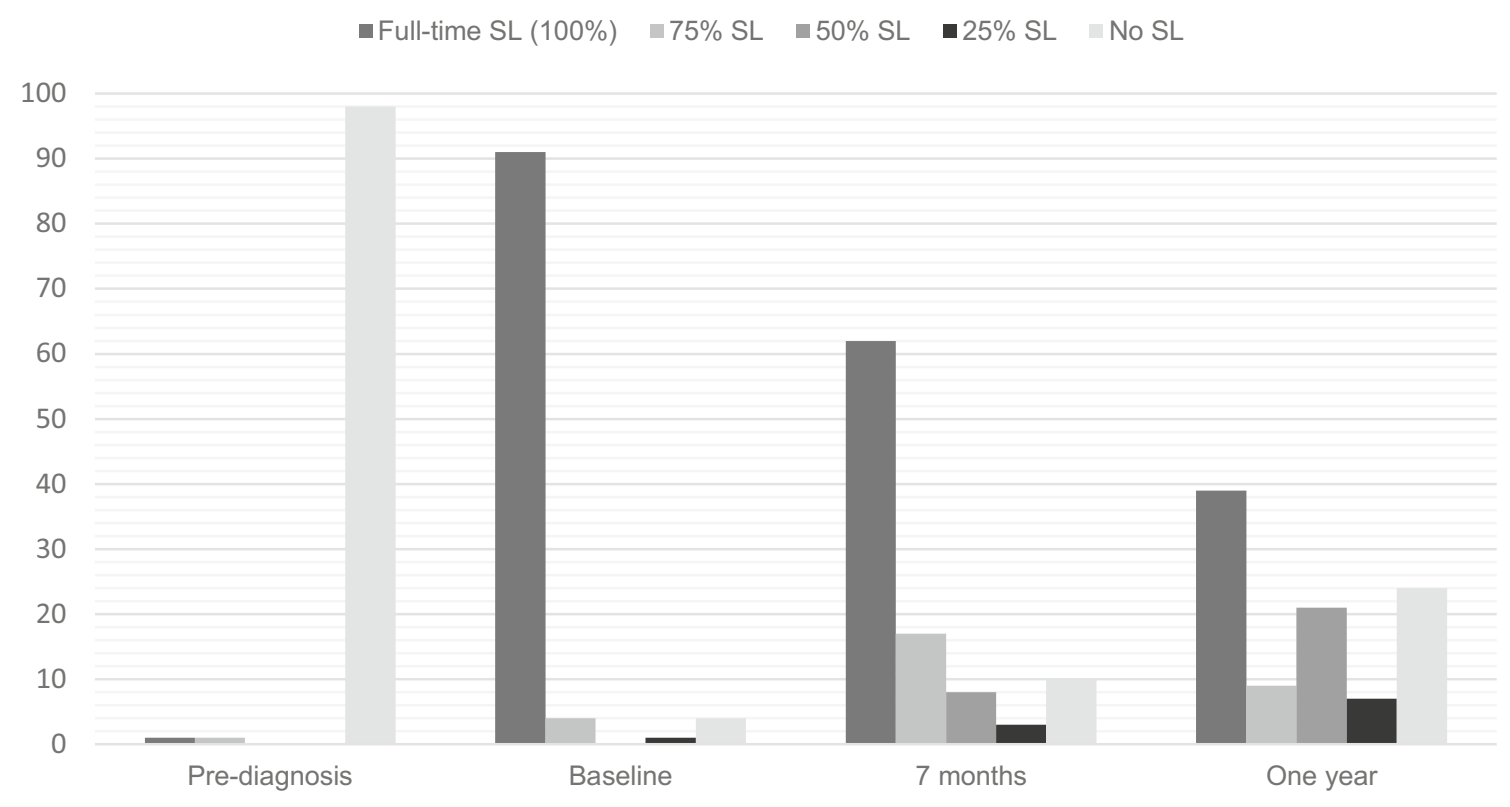

Fig. 2 Proportions of participants (\%) on SL at the different time points $(n=122)$ 
Table 2 Descriptions of proportions of demographic, medical and psychological factors along with satisfaction with vocational and financial situation and odds ratio (OR) with 95\% confidence interval (CI) for those on full-time SL $(n=48)$ at the 1-year follow-up among all participants $(n=122)$

\begin{tabular}{|c|c|c|c|c|c|c|c|}
\hline Independent variable & & $\begin{array}{l}\text { Total } \\
(n=122) \\
n(\%)\end{array}$ & $\begin{array}{l}\text { Full-time SL } \\
(n=48) \\
n(\%)\end{array}$ & $\begin{array}{l}\text { Univariable } \\
\text { analysis } \\
\text { OR }(95 \% \mathrm{CI})\end{array}$ & $\begin{array}{l}p \\
\text { value }\end{array}$ & $\begin{array}{l}\text { Multivariable } \\
\text { analysis } \\
\text { OR }(95 \% \mathrm{CI})\end{array}$ & $\begin{array}{l}p \\
\text { value }\end{array}$ \\
\hline \multicolumn{8}{|l|}{ Demographic factors } \\
\hline Gender & $\begin{array}{l}\text { Female } \\
\text { Male (ref) }\end{array}$ & $\begin{array}{l}49(40) \\
73(60)\end{array}$ & $\begin{array}{l}20(41) \\
28(38)\end{array}$ & $\begin{array}{l}1.11 \\
(0.53-2.32)\end{array}$ & 0.79 & & \\
\hline Age & $\begin{array}{l}\text { Older } \\
\text { Younger (ref) }\end{array}$ & $\begin{array}{l}64(52) \\
58(48)\end{array}$ & $\begin{array}{l}26(41) \\
22(38)\end{array}$ & $\begin{array}{l}1.12 \\
(0.54-2.32)\end{array}$ & 0.76 & & \\
\hline Education & $\begin{array}{l}\text { Lower } \\
\text { Higher (ref) }\end{array}$ & $\begin{array}{l}45(38) \\
74(62)\end{array}$ & $\begin{array}{l}19(42) \\
28(38)\end{array}$ & $\begin{array}{l}1.2 \\
(0.56-2.56)\end{array}$ & 0.64 & & \\
\hline Living situation & $\begin{array}{l}\text { Living alone } \\
\text { Living with someone (ref) }\end{array}$ & $\begin{array}{l}17(14) \\
102(86)\end{array}$ & $\begin{array}{l}8(47) \\
39(38)\end{array}$ & $\begin{array}{l}1.44 \\
(0.51-4.03)\end{array}$ & 0.49 & & \\
\hline \multicolumn{8}{|l|}{ Medical factors } \\
\hline Diagnosis & $\begin{array}{l}\text { Acute leukaemia } \\
\text { All others (ref) }\end{array}$ & $\begin{array}{l}53(43) \\
69(57)\end{array}$ & $\begin{array}{l}18(34) \\
30(44)\end{array}$ & $\begin{array}{l}0.7 \\
(0.32-1.4)\end{array}$ & 0.29 & & \\
\hline Conditioning & $\begin{array}{l}\text { Myeloablative (MAC) } \\
\text { Reduced intensity (RIC) } \\
\quad \text { (ref) }\end{array}$ & $\begin{array}{l}38(31) \\
84(69)\end{array}$ & $\begin{array}{l}15(40) \\
33(39)\end{array}$ & $\begin{array}{l}1.0 \\
(0.46-2.21)\end{array}$ & 0.98 & & \\
\hline Total body irradiation & $\begin{array}{l}\text { Yes } \\
\text { No (ref) }\end{array}$ & $\begin{array}{l}36(30) \\
86(70)\end{array}$ & $\begin{array}{l}14(39) \\
34(40)\end{array}$ & $\begin{array}{l}0.97 \\
(0.44-2.16)\end{array}$ & 0.95 & & \\
\hline cGvHD (at 1 year) & $\begin{array}{l}\text { Yes } \\
\text { No (ref) }\end{array}$ & $\begin{array}{l}32(26) \\
90(74)\end{array}$ & $\begin{array}{l}19(59) \\
29(32)\end{array}$ & $\begin{array}{l}3.07 \\
(1.34-7.07)\end{array}$ & 0.01 & $\begin{array}{l}3.43 \\
(1.35-8.73)\end{array}$ & 0.01 \\
\hline $\begin{array}{l}\text { Relapse (during 1st year after } \\
\text { allo-HSCT) }\end{array}$ & $\begin{array}{l}\text { Yes } \\
\text { No (ref) }\end{array}$ & $\begin{array}{l}14(11) \\
108(89)\end{array}$ & $\begin{array}{l}9(64) \\
39(36)\end{array}$ & $\begin{array}{l}3.19 \\
(1.00-10.18)\end{array}$ & 0.05 & & \\
\hline \multicolumn{8}{|l|}{ Psychological factors } \\
\hline Symptoms of anxiety at baseline & $\begin{array}{l}\text { Case } \\
\text { Non-case (ref) }\end{array}$ & $\begin{array}{l}29(25) \\
87(75)\end{array}$ & $\begin{array}{l}15(52) \\
31(36)\end{array}$ & $\begin{array}{l}1.94 \\
(0.83-4.53)\end{array}$ & 0.13 & & \\
\hline Symptoms of anxiety at 7 months & $\begin{array}{l}\text { Case } \\
\text { Non-case (ref) }\end{array}$ & $\begin{array}{l}28(24) \\
90(76)\end{array}$ & $\begin{array}{l}12(43) \\
34(38)\end{array}$ & $\begin{array}{l}1.24 \\
(0.52-2.92)\end{array}$ & 0.63 & & \\
\hline Symptoms of depression at baseline & $\begin{array}{l}\text { Case } \\
\text { Non-case (ref) }\end{array}$ & $\begin{array}{l}24(21) \\
90(79)\end{array}$ & $\begin{array}{l}12(50) \\
33(37)\end{array}$ & $\begin{array}{l}1.73 \\
(0.7-4.28)\end{array}$ & 0.24 & & \\
\hline Symptoms of depression at 7 months & $\begin{array}{l}\text { Case } \\
\text { Non-case (ref) }\end{array}$ & $\begin{array}{l}20(17) \\
98(83)\end{array}$ & $\begin{array}{l}14(70) \\
32(33)\end{array}$ & $\begin{array}{l}4.81 \\
(1.69-13.69)\end{array}$ & & $\begin{array}{l}3.73 \\
(1.2-11.58)\end{array}$ & 0.02 \\
\hline \multicolumn{8}{|c|}{ Vocational and economical satisfaction } \\
\hline Vocational situation at baseline & $\begin{array}{l}\text { Low } \\
\text { High (ref) }\end{array}$ & $\begin{array}{l}63(55) \\
52(45)\end{array}$ & $\begin{array}{l}28(44) \\
18(35)\end{array}$ & $\begin{array}{l}1.51 \\
(0.71-3.22)\end{array}$ & 0.29 & & \\
\hline Vocational situation at 7 months & $\begin{array}{l}\text { Low } \\
\text { High (ref) }\end{array}$ & $\begin{array}{l}79(71) \\
33(29)\end{array}$ & $\begin{array}{l}37(47) \\
7(21)\end{array}$ & $\begin{array}{l}3.27 \\
(1.27-8.41)\end{array}$ & 0.01 & $\begin{array}{l}2.79 \\
(1.0-7.75)\end{array}$ & $\begin{array}{l}\mathrm{NS} \\
(0.05)\end{array}$ \\
\hline Financial situation at baseline & $\begin{array}{l}\text { Low } \\
\text { High (ref) }\end{array}$ & $\begin{array}{l}56(49) \\
58(51)\end{array}$ & $\begin{array}{l}25(45) \\
20(35)\end{array}$ & $\begin{array}{l}1.53 \\
(0.72-3.26)\end{array}$ & 0.27 & & \\
\hline Financial situation at 7 months & $\begin{array}{l}\text { Low } \\
\text { High (ref) }\end{array}$ & $\begin{array}{l}73(63) \\
43(37)\end{array}$ & $\begin{array}{l}30(41) \\
15(35)\end{array}$ & $\begin{array}{l}1.3 \\
(0.6-2.85)\end{array}$ & 0.51 & & \\
\hline
\end{tabular}

$O R$, odds ratio; $C I$, confidence interval

can easily adapt their employment to reduce the risk of becoming infected with, for example, community acquired respiratory viruses such as influenza and respiratory syncytial virus. This recommendation is prolonged if at 6 months posttreatment a patient is still on full immunosuppression for GvHD. This is a unique situation not applicable to most other cancer patients, and the current Covid-19 pandemic has only increased the need for this type of self-protection from respiratory viruses in allo-HSCT patients [40].

None of the demographic factors investigated in this study were associated with full-time SL 1 year after allo-HSCT. However, sociodemographic factors have previously been shown to be associated with SL and RTW. In a large study including different types of cancer diagnoses, higher age and lower education predicted longer SL [41], while studies focusing on RTW among allo-HSCT survivors found that those of female gender and older age were less likely to RTW [7, 4], whereas no associations with educational level were found [7]. These differences may depend on when the measurements of RTW were done or be due to other factors being more important, as allo-HSCT survivors often face complications and a slow immune reconstitution $[2,3]$.

The medical factor cGvHD was significantly associated with full-time SL 1 year after allo-HSCT both in univariable 
and multivariable analyses, which is not surprising and in agreement with two earlier studies focusing on RTW $[9,11]$. Previous studies show that survivors with cGvHD experience significant functional limitations in areas such as mental health $[9,12]$, quality of life $[9,42]$ and overall survival $[43$, 44]. Interestingly, relapse during the first year after allo-HSCT was not associated with full-time SL 1 year after transplantation. Previous research in autologous HSCT patients has found that relapse of the primary disease was associated with a lower likelihood of RTW in the first year after treatment [11] along with a decreased rate of RTW for patients who were on $\mathrm{SL}$ at the time of relapse [33]. The results suggest that those included in this study who relapsed during the first year after allo-HSCT were treated successfully, as they were able to participate in the study at the 1-year follow-up. Unsuccessful treatment of relapse after allo-HSCT often results in death, which in this study resulted in a lack of data at the 1-year follow-up on those most affected by relapse.

The present results show that having symptoms of depression at 7 months after treatment, but not at baseline, was associated with full-time SL 1 year after allo-HSCT. No previous studies have been found that specifically explore associations between depression and SL after allo-HSCT. However, although it is known that depression negatively affects RTW after injury or illness in general [45], this has not been shown among patients with a haematological malignancy [8]. Nevertheless, one study indicated that being unemployed is linked to depression after allo-HSCT [13]. It can be questioned whether having anxiety and depression symptoms make a person remain on SL or if SL itself increases the risk of developing these symptoms. Regardless of the cause, it is important to be aware that after allo-HSCT patients are at risk of anxiety, depression [14, 12, 15] and cGvHD [9] and that these appear to be interrelated as studies show associations between cGvHD and mental health $[9,12]$. Thus, it is important to identify those who are at risk of depression. More indepth, qualitative research would be of interest to further explore the ways in which depression can affect allo-HSCT survivors.

A factor associated with SL in the univariable analysis was low vocational satisfaction at 7 months, but not at baseline, after allo-HSCT. This is in line with studies of breast cancer patients, where low vocational satisfaction 6 weeks postsurgery predicted non-RTW 10 months after surgery [18]. Also, significant associations have been found between vocational dissatisfaction and long-term SL among non-cancer patients $[16,17]$. Vocational satisfaction can be dependent on whether the patient has employment to return to as it is difficult to judge from the present results whether low satisfaction is due to SL or vice versa. An American study found that it is common for allo-HSCT patients to experience serious adverse financial consequences [46]. Therefore, it is worth noting that satisfaction with the current financial situation was not associated with full-time SL in the present study. This may be due to the Swedish context where the national social insurance system financially compensates patients for loss of earnings following injury or illness.

A strength of this study is the inclusion of longitudinal data and a relatively large sample size, considering that approximately only 400 allo-HSCT are performed annually in Sweden. However, it is still possible that a larger sample size might have yielded different results. A limitation is the lack of information regarding SL of those who were not invited to participate, especially as the reasons for not being included are unknown. Another strength is the use of clinically diagnosed cGvHD data, as many other studies only use selfreported data, which could be considered uncertain due to subjectivity. The lack of participants diagnosed with severe cGvHD means that those most affected by cGvHD were not included, possibly because they either dropped out or died. In the logistic regression analyses, the presence rather than the severity of cGvHD was analysed, which could have influenced the cGvHD results. However, analyses of the severity of cGvHD were also performed and showed similar results. In addition, the likelihood of participants being classified as having symptoms of depression might be overestimated in this study since symptoms of depression were measured using the HADS self-assessment scale and not diagnosed by a clinician. However, HADS has been found to have excellent case finding abilities in many settings [29]. In this study, data on SL is from the 1-year follow-up. A suggestion for further studies in this patient group would be to examine self-reported reasons for SL, and report on SL further along the trajectory than 1 year as earlier research has shown that RTW is a long process for this patient group [47].

In conclusion, this study appears to be the only study examining SL and factors associated with full-time SL 1 year after allo-HSCT. The results show that a large proportion of allo-HSCT survivors are still on full-time SL 1 year after treatment and that cGvHD and depressive symptoms may be associated with SL. These results suggest that it is important for health care staff to closely monitor and manage the consequences of cGvHD and be observant of and find appropriate care strategies for patients' symptoms of depression in the aftermath of allo-HSCT to increase the likelihood of a successful RTW.

Acknowledgements We would like to thank the patients who participated in this study along with the health care staff who helped with the inclusion of participants at the CAST transplantation unit, Karolinska University Hospital, Stockholm, Sweden. Furthermore, the authors would like to thank Davide Valentini for his help in retrieving the participants' medical information.

Author contribution All authors contributed to the study conception and design. Material preparation was performed by Jeanette Winterling, Karin Bergkvist and Agneta Wennman-Larsen and data collection and analysis 
were performed by Linda Eriksson. The first draft of the manuscript was written by Linda Eriksson and all authors commented on previous versions of the manuscript. All authors read and approved the final manuscript.

Funding Open Access funding provided by Karolinska Institute. Partial financial support was received by Blodcancerfonden and Leukemifonden, Karolinska University Hospital, Stockholm, Sweden.

Data availability The datasets generated and/or analysed during the current study are available from the corresponding author on reasonable request.

\section{Compliance with ethical standards}

Conflict of interest The authors declare that they have no conflicts of interest.

Ethics approval This study was performed in accordance with the principles of the 1964 Declaration of Helsinki and its later amendments. Approval was granted by the Regional Ethical Review Board in Stockholm, Sweden (dnr 2008/1732-31/2).

Consent to participate Informed consent was obtained from all individual participants included in the study.

Financial interests The authors declare they have no financial interests.

Open Access This article is licensed under a Creative Commons Attribution 4.0 International License, which permits use, sharing, adaptation, distribution and reproduction in any medium or format, as long as you give appropriate credit to the original author(s) and the source, provide a link to the Creative Commons licence, and indicate if changes were made. The images or other third party material in this article are included in the article's Creative Commons licence, unless indicated otherwise in a credit line to the material. If material is not included in the article's Creative Commons licence and your intended use is not permitted by statutory regulation or exceeds the permitted use, you will need to obtain permission directly from the copyright holder. To view a copy of this licence, visit http://creativecommons.org/licenses/by/4.0/.

\section{References}

1. Beres AJ, Drobyski WR. The role of regulatory T cells in the biology of graft versus host disease. Front Immunol. 2013;4:163. https://doi.org/10.3389/fimmu.2013.00163.

2. Majhail NS, Rizzo JD. urviving the cure: long term followup of hematopoietic cell transplant recipients. Bone Marrow Transplant. 2013;48(9):1145-51. https://doi.org/10.1038/bmt.2012.258.

3. Syrjala KL, Martin PJ, Lee SJ. Delivering care to long-term adult survivors of hematopoietic cell transplantation. J Clin Oncol. 2012;30(30):3746-51. https://doi.org/10.1200/JCO.2012.42.3038.

4. Winterling J, Johansson E, Wennman-Larsen A, Petersson LM, Ljungman P, Alexanderson K. Occupational status among adult survivors following allo-SCT. Bone Marrow Transplant. 2014;49(6):836-42. https://doi.org/10.1038/bmt.2014.26.

5. Johansson E, Larsen J, Schempp T, Jonsson L, Winterling J. Patients' goals related to health and function in the first 13 months after allogeneic stem cell transplantation. Support Care Cancer. 2012;20(9):2025-32. https://doi.org/10.1007/s00520-011-1310-x.
6. Morrison EJ, Ehlers SL, Bronars CA, Patten CA, Brockman TA, Cerhan JR, et al. Employment status as an indicator of recovery and function one year after hematopoietic stem cell transplantation. Biol Blood Marrow Transplant. 2016;22(9):1690-5. https://doi.org/10. 1016/j.bbmt.2016.05.013.

7. Kirchhoff AC, Leisenring W, Syrjala KL. Prospective predictors of return to work in the 5 years after hematopoietic cell transplantation. J Cancer Surviv. 2010;4(1):33-44. https://doi.org/10.1007/ s11764-009-0105-2.

8. Horsboel TA, Bultmann U, Nielsen CV, Nielsen B, Andersen NT, de Thurah A. Are fatigue, depression and anxiety associated with labour market participation among patients diagnosed with haematological malignancies? A prospective study. Psycho-oncology. 2015;24(4):408-15. https://doi.org/10.1002/pon.3658.

9. Lee SJ, Onstad L, Chow EJ, Shaw BE, Jim HSL, Syrjala KL, et al. Patient-reported outcomes and health status associated with chronic graft-versus-host disease. Haematologica. 2018;103(9):1535-41. https://doi.org/10.3324/haematol.2018.192930.

10. Syrjala KL, Langer SL, Abrams JR, Storer B, Sanders JE, Flowers $\mathrm{ME}$, et al. Recovery and long-term function after hematopoietic cell transplantation for leukemia or lymphoma. Jama. 2004;291(19): 2335-43. https://doi.org/10.1001/jama.291.19.2335.

11. Wong FL, Francisco L, Togawa K, Bosworth A, Gonzales M, Hanby C, et al. Long-term recovery after hematopoietic cell transplantation: predictors of quality-of-life concerns. Blood. 2010;115(12):2508-19. https://doi.org/10.1182/blood-2009-06225631.

12. El-Jawahri A, Pidala J, Khera N, Wood WA, Arora M, Carpenter $\mathrm{PA}$, et al. Impact of psychological distress on quality of life, functional status, and survival in patients with chronic graft-versus-host disease. Biol Blood Marrow Transplant. 2018;24(11):2285-92. https://doi.org/10.1016/j.bbmt.2018.07.020.

13. Gruber U, Fegg M, Buchmann M, Kolb HJ, Hiddemann W. The long-term psychosocial effects of haematopoetic stem cell transplantation. Eur J Cancer Care (Engl). 2003;12(3):249-56.

14. Ferry C, Gemayel G, Rocha V, Labopin M, Esperou H, Robin M, et al. Long-term outcomes after allogeneic stem cell transplantation for children with hematological malignancies. Bone Marrow Transplant. 2007;40(3):219-24. https://doi.org/10.1038/sj.bmt. 1705710.

15. Kuba K, Esser P, Mehnert A, Johansen C, Schwinn A, Schirmer L, et al. Depression and anxiety following hematopoietic stem cell transplantation: a prospective population-based study in Germany. Bone Marrow Transplant. 2017;52(12):1651-7. https://doi.org/10. 1038/bmt.2017.190.

16. Mirmohammadi SJ, Sadr-Bafghi SM, Mehrparvar AH, Gharavi M, Davari MH, Bahaloo M, et al. Evaluation of the return to work and its duration after myocardial infarction. ARYA Atheroscler. 2014;10(3):137-40.

17. van der Giezen AM, Bouter LM, Nijhuis FJ. Prediction of return-towork of low back pain patients sicklisted for 3-4 months. Pain. 2000;87(3):285-94. https://doi.org/10.1016/s0304-3959(00) 00292-x.

18. Johnsson A, Fornander T, Rutqvist LE, Olsson M. Work status and life changes in the first year after breast cancer diagnosis. Work (Reading, Mass). 2011;38(4):337-46. https://doi.org/10.3233/ WOR-2011-1137.

19. Olsson M, Nilsson M, Fugl-Meyer K, Petersson LM, WennmanLarsen A, Kjeldgard L, et al. Life satisfaction of women of working age shortly after breast cancer surgery. Qual Life Res. 2017;26(3): 673-84. https://doi.org/10.1007/s11136-016-1479-z.

20. Bryngelson A. Long-term sickness absence and social exclusio. Scand J Public Health. 2009;37(8):839-45. https://doi.org/10. 1177/1403494809346871.

21. Eriksson H-G, von Celsing A-S, Wahlström R, Janson L, Zander V, Wallman T. Sickness absence and self-reported health a population- 
based study of 43,600 individuals in central Sweden. BMC Public Health. 2008;8(1):426.

22. Floderus B, Goransson S, Alexanderson K, Aronsson G. Selfestimated life situation in patients on long-term sick leave. $\mathrm{J}$ Rehabil Med. 2005;37(5):291-9. https://doi.org/10.1080/ 16501970510034422.

23. Sieurin L, Josephson M, Vingård E. Positive and negative consequences of sick leave for the individual, with special focus on parttime sick leave. Scand J Public Health. 2009;37(1):50-6. https:// doi.org/10.1177/1403494808097171.

24. Edwards S, Gabbay M. Living and working with sickness: a qualitative study. Chronic Illn. 2007;3(2):155-66. https://doi.org/10. $1177 / 1742395307082124$.

25. De Wolfe P. Reaping the benefits of sickness? Long-term illness and the experience of welfare claims. Disabil Soc. 2012;27(5):61730. https://doi.org/10.1080/09687599.2012.669107.

26. Petersson LM, Wennman-Larsen A, Nilsson M, Olsson M, Alexanderson K. Work situation and sickness absence in the initial period after breast cancer surgery. Acta Oncol. 2011;50(2):282-8. https://doi.org/10.3109/0284186X.2010.533191.

27. Bergkvist K, Winterling J, Johansson E, Johansson UB, Svahn BM, Remberger M, et al. General health, symptom occurrence, and selfefficacy in adult survivors after allogeneic hematopoietic stem cell transplantation: a cross-sectional comparison between hospital care and home care. Support Care Cancer. 2015;23(5):1273-83. https:// doi.org/10.1007/s00520-014-2476-9.

28. Zigmond AS, Snaith RP. The hospital anxiety and depression scale. Acta Psychiatr Scand. 1983;67(6):361-70. https://doi.org/10.1111/ j.1600-0447.1983.tb09716.x.

29. Bjelland I, Dahl AA, Haug TT, Neckelmann D. The validity of the hospital anxiety and depression scale. An updated literature review. J Psychosom Res. 2002;52(2):69-77.

30. Fugl-Meyer AR, Melin R, Fugl-Meyer KS. Life satisfaction in 18to 64-year-old Swedes: in relation to gender, age, partner and immigrant status. J Rehabil Med. 2002;34(5):239-46. https://doi.org/ $10.1080 / 165019702760279242$.

31. Bell ML, Fairclough DL, Fiero MH, Butow PN. Handling missing items in the Hospital Anxiety and Depression Scale (HADS): a simulation study. BMC Res Notes. 2016;9(1):479. https://doi.org/ 10.1186/s13104-016-2284-z.

32. Downey RG, King C. Missing data in Likert ratings: a comparison of replacement methods. J Gen Psychol. 1998;125(2):175-91. https://doi.org/10.1080/00221309809595542.

33. Arboe B, Olsen MH, Goerloev JS, Duun-Henriksen AK, Johansen C, Dalton SO, et al. Return to work for patients with diffuse large B cell lymphoma and transformed indolent lymphoma undergoing autologous stem cell transplantation. Clin Epidemiol. 2017;9:3219. https://doi.org/10.2147/clep.s134603.

34. Balak F, Roelen CA, Koopmans PC, Ten Berge EE, Groothoff JW. Return to work after early-stage breast cancer: a cohort study into the effects of treatment and cancer-related symptoms. J Occup Rehabil. 2008;18(3):267-72. https://doi.org/10.1007/s10926-0089146-z.

35. Fantoni SQ, Peugniez C, Duhamel A, Skrzypczak J, Frimat P, Leroyer A. Factors related to return to work by women with breast cancer in northern France. J Occup Rehabil. 2010;20(1):49-58. https://doi.org/10.1007/s10926-009-9215-y.

36. Paltrinieri S, Vicentini M, Mazzini E, Ricchi E, Fugazzaro S, Mancuso P, et al. Factors influencing return to work of cancer survivors: a population-based study in Italy. Support Care Cancer. 2020;28(2):701-12. https://doi.org/10.1007/s00520-019-04868-0.

37. van Muijen P, Weevers NL, Snels IA, Duijts SF, Bruinvels DJ, Schellart AJ, et al. Predictors of return to work and employment in cancer survivors: a systematic review. Eur J Cancer Care (Engl). 2013;22(2):144-60. https://doi.org/10.1111/ecc. 12033.

38. Petersson LM, Vaez M, Nilsson MI, Saboonchi F, Alexanderson K, Olsson M, et al. Sickness absence following breast cancer surgery: a two-year follow-up cohort study. Scand J Caring Sci. 2018;32(2): 715-24. https://doi.org/10.1111/scs.12502.

39. Amir Z, Moran T, Walsh L, Iddenden R, Luker K. Return to paid work after cancer: a British experience. J Cancer Surviv. 2007;1(2): 129-36. https://doi.org/10.1007/s11764-007-0021-2.

40. Ljungman P, Mikulska M, de la Camara R, Basak GW, Chabannon $\mathrm{C}$, Corbacioglu S, et al. The challenge of COVID-19 and hematopoietic cell transplantation; EBMT recommendations for management of hematopoietic cell transplant recipients, their donors, and patients undergoing CAR T cell therapy. Bone Marrow Transplant. 2020:1-6. https://doi.org/10.1038/s41409-020-0919-0.

41. Torp S, Nielsen RA, Gudbergsson SB, Fossa SD, Dahl AA. Sick leave patterns among 5-year cancer survivors: a registry-based retrospective cohort study. J Cancer Surviv. 2012;6(3):315-23. https://doi.org/10.1007/s11764-012-0228-8.

42. Pidala J, Kurland B, Chai X, Majhail N, Weisdorf DJ, Pavletic S, et al. Patient-reported quality of life is associated with severity of chronic graft-versus-host disease as measured by NIH criteria: report on baseline data from the Chronic GVHD Consortium. Blood. 2011;117(17):4651-7. https://doi.org/10.1182/blood-2010-11319509.

43. Grube M, Holler E, Weber D, Holler B, Herr W, Wolff D. Risk factors and outcome of chronic graft-versus-host disease after allogeneic stem cell transplantation-results from a single-center observational study. Biol Blood Marrow Transplant. 2016;22(10):178191. https://doi.org/10.1016/j.bbmt.2016.06.020.

44. Afram G, Watz E, Remberger M, Nygell UA, Sundin M, Hagglund $\mathrm{H}$, et al. Higher response rates in patients with severe chronic skin graft-versus-host disease treated with extracorporeal photopheresis. Cent Eur J Immunol. 2019;44(1):84-91. https://doi.org/10.5114/ ceji.2018.75831.

45. Cancelliere C, Donovan J, Stochkendahl MJ, Biscardi M, Ammendolia C, Myburgh C, et al. Factors affecting return to work after injury or illness: best evidence synthesis of systematic reviews. Chiropr Man Ther. 2016;24(1):32. https://doi.org/10.1186/ s12998-016-0113-z.

46. Khera N, Chang YH, Hashmi S, Slack J, Beebe T, Roy V, et al. Financial burden in recipients of allogeneic hematopoietic cell transplantation. Biol Blood Marrow Transplant. 2014;20(9):137581. https://doi.org/10.1016/j.bbmt.2014.05.011.

47. Winterling J, Johansson E, Wettergren L, Ljungman P, Alexanderson K. Occupational status among adult survivors following allogeneic stem cell transplantation in childhood. Eur $\mathrm{J}$ Cancer Care. 2018;27(2):e12808. https://doi.org/10.1111/ecc. 12808.

Publisher's note Springer Nature remains neutral with regard to jurisdictional claims in published maps and institutional affiliations. 